\title{
INFLUENCE OF DISTANCE, GEOMETRY AND NUMBER OF CONTROL STATIONS ON QUALITY OF LOCAL GEODETIC NETWORKS FOR THE PURPOSE OF GEOREFERENCING OF RURAL PROPERTIES
}

\section{DAVID LUCIANO ROSALEN ${ }^{1}$}

\begin{abstract}
The implementation of local geodetic networks for georeferencing of rural properties has become a requirement after publication of the Georeferencing Technical Standard by INCRA. According to this standard, the maximum distance of baselines to GNSS L1 receivers is of $20 \mathrm{~km}$. Besides the length of the baseline, the geometry and the number of geodetic control stations are other factors to be considered in the implementation of geodetic networks. Thus, this research aimed to examine the influence of baseline lengths higher than the regulated limit of $20 \mathrm{~km}$, the geometry and the number of control stations on quality of local geodetic networks for georeferencing, and also to demonstrate the importance of using specific tests to evaluate the solution of ambiguities and on the quality of the adjustment. The results indicated that the increasing number of control stations has improved the quality of the network, the geometry has not influenced on the quality and the baseline length has influenced on the quality; however, lengths higher than $20 \mathrm{~km}$ has not interrupted the implementation, with GPS L1 receiver, of the local geodetic network for the purpose of georeferencing. Also, the use of different statistical tests, both for the evaluation of the resolution of ambiguities and for the adjustment, have enabled greater clearness in analyzing the results, which allow that unsuitable observations may be eliminated.
\end{abstract}

KEYWORDS: GNSS, baseline, Law 10,267/2001.

\section{INFLUÊNCIA DA DISTÂNCIA, GEOMETRIA E NÚMERO DE ESTAÇÕES DE CONTROLE NA QUALIDADE DE REDES GEODÉSICAS LOCAIS PARA FINS DE GEORREFERENCIAMENTO DE IMÓVEIS RURAIS}

RESUMO: A implantação de redes geodésicas locais para fins de georreferenciamento de imóveis rurais tornou-se uma obrigatoriedade após a publicação da Norma Técnica de Georreferenciamento pelo INCRA. Conforme essa norma, a distância máxima de linhas-base para receptores GNSSL1 é de $20 \mathrm{~km}$. Além do comprimento da linha-base, a geometria e o número de estações geodésicas de controle são outros fatores a serem considerados na implantação de redes geodésicas. Dessa forma, o objetivo do trabalho foi verificar a influência de comprimentos de linhas-base superiores ao limite normatizado de $20 \mathrm{~km}$, da geometria e do número de estações de controle, na qualidade de redes geodésicas locais para fins de georreferenciamento e, também, demonstrar a importância da utilização de testes específicos na avaliação da solução das ambiguidades e na qualidade do ajustamento. Os resultados indicaram que o aumento do número de estações de controle melhorou a qualidade da rede, que a geometria não influenciou na qualidade e que o comprimento de linha-base sim; mas comprimentos superiores a $20 \mathrm{~km}$ não inviabilizaram a implantação, com receptor GPS L1, de rede geodésica local para fins de georreferenciamento. Também, que a utilização de diferentes testes estatísticos, tanto para a avaliação da solução das ambiguidades como para o ajustamento, permitiu maior clareza na análise dos resultados, possibilitando, inclusive, que observações não adequadas possam ser eliminadas.

PALAVRAS-CHAVE: GNSS, linha-base, Lei 10.267/2001.

\footnotetext{
${ }^{1}$ Engo Agrônomo, Prof. Doutor, Departamento de Engenharia Rural, FCAV/UNESP, Jaboticabal -SP, rosalen@fcav.unesp.br Recebido pelo Conselho Editorial em: 10-7-2012 


\section{INTRODUCTION}

Law 10.267 of 08/28/2001 aimed the creation of the National Registration of Rural Property (NRRP) and requires the georeferencing of the rural properties. The technical procedure for georeferencing is described by the Technical Standard for Georreferencing of Rural Properties, second edition (INCRA, 2010).

In the implementation of a support base station to georeferencing (Class C1 point as the standard of georeferencing), the Relative Static or Precise Point positioning is utilized. In the case of relative positioning, the use of at least two geodetic stations of the Brazilian Geodetic System SGB (control stations) is required. Also, the survey needs to be adjusted by the Method of Least Squares - MLS (INCRA, 2010). Thus, the implementation of a small local geodetic network and the use, virtually mandatory, of global navigation satellite systems (GNSS) occurs. It is noteworthy that GNSS systems have applications other than geodesy and georeferencing, such as precision agriculture (ROSALEN et al., 2011b) and meteorology (HOLZSCHUH et al., 2010).

The basic function of geodetic networks is the materialization of a geodetic system, providing the necessary support for several purposes. The geodetic networks may have a purely local scope, as in georeferencing and in work control (GRANEMANN et al., 2008) or wider as municipal (MONICO et al., 1998.) and state networks (VASCONCELLOS \& BLITZKOW, 2003; RODRIGUES, 2002; FREITAS et al., 1998).

The maximum distance of baselines for GNSSL1 receivers, as required by georeferencing standard, is $20 \mathrm{~km}$. This requirement limits the use of this type of receiver, in view of certain limitations of the geodetic infrastructure available in Brazil, which requires professionals who work in the georeferencing to work with dual frequency GNSS receivers (L1L2 receivers), more expensive equipment and therefore, with more restricted access. Rosalen (2011a) states that it is essential to professionals working in georeferencing, to use the GNSSL1L2 receivers, because this category of receivers allows the use of the data provided by the Brazilian Network for Continuous Monitoring (BNCM), which has a satisfactory coverage in Brazil.

It is noteworthy that the resolution of ambiguities in the phase of carrier wave, in GNSS relative positioning, such as integers, is fundamental to ensuring the quality of positioning and is therefore also a requirement of the georeferencing standard. It is noteworthy that the time of screening in geodetic surveys is of utmost importance to resolve the ambiguity of the observations (ARANA et al., 1997; CATEN \& ROBAIANA, 2005).

However, even getting a fixed solution to the ambiguities, this may not be acceptable, hence the need to establish measures for the validation of this solution. The ratio statistic is one of the best known measures to evaluate the solution of ambiguities. It is a test of discrimination based on quadratic relationship between waste, vector of ambiguities, the second and the entire first best solution (MONICO, 2008). One of the issues surrounding this test is to determine the critical value. This value is determined empirically, ranging from author to author. For example, in Monico (2008), there are references to values equal to two or three, and to five or ten. The value three is highly adopted in software such as Leick quotes (2004 apud MONICO, 2008).

In the implementation of basic support for georeferencing from two control stations of the SGB, the formation of a single triangle whose vertices are the geodetic stations occurs. Evaluate whether the geometry of the arrangement of stations will influence the quality of the coordinates to be determined for the base station support is important because the distribution of the control stations is not always uniform. According to MARINI AND MONICO (2003), few studies assess the geometry of the arrangement of stations in geodetic network. EVEN-TZUR \& PAPO (1996) apud MARINI \& MONICO (2003) state that the geometry of the arrangement of stations do not interfere on the final result; however, the length of the baselines interfere and should be the lowest possible. 
The standard georeferencing of rural properties requires a minimum of two control stations, for thereby becomes possible to adjust, since the number of observations exceeds the number of unknowns. However, it may occur situations with a large number of available control stations and, therefore, it is also interesting to evaluate the impact of the use of a greater number of stations on the network adjustment, because it is expected that as it increase the number of observations, since these have similar qualities, the adjusted value will have lower waste, therefore a better quality will be obtained. It is noteworthy that the adjustment of geodetic networks is performed by MLS and is fundamental to evaluate the result of the adjustment through specific statistical tests.

The Global Test Model (GTM) and the Data Snooping Test, originally proposed by BAARDA (1968), are tests belonging to the same family and are based on the likelihood ratio, as quoted by TEUNISSEM (2006) apud KLEIN et al. (2011). The GTM evaluate if the residuals of the adjustment fit within the expected limits, validating the adjustment performed. It is noteworthy that the GTM can be applied using the $\chi^{2}$ Test or the $\mathrm{F}$ Test because both tests compares variances (COSTA NETO, 2002). As proposed by BAARDA (1968), when the GTM shows unsatisfactory results, you should apply a test for the detection of gross errors. It is noteworthy that the gross errors are the cause of discordant observations (outliers); it is considered as one discordant observation that contradicts a certain statistical property, for example, the expected uncertainty of observation.

The Data Snooping test, proposed by BAARDA (1968), is named when each observation of geodetic network is tested by $\mathrm{W}$ Test. This test is used to detect gross errors and, when it is not accepted, there is the indication that a particular gross error contaminates their observation. We can find more details about these tests in POPE (1976), OLIVEIRA \& DALMOLIN (2008), GÖKALPET al. (2008) and GULLU \& YILMAZ (2010).

The family of tests which include the GTM and the Data Snooping is based on statistical hypothesis; therefore, have associated probability levels and thus have a finite capacity to detect non-random errors of small magnitude. Also, these tests do not quantify the magnitude of the errors present in the observations. Thus, it becomes necessary to establish measures that indicate how much the observation are reliable. Within this context, BAARDA (1968) proposed the Theory of Reliability. As measures of reliability there is the Internal Reliability or MinimalDetectable Bias (MDB) and the External Reliability or Bias toNoiseRatio (BNR). The MDB from a given observation indicates the magnitude of the smallest detectable error of this observation with a given probability (TEIXEIRA \& FERREIRA, 2003; KLEIN et al., 2011). The BNR of a given observation indicates the influence of MDB observation in the final results of the adjustment, i.e., the fitted parameters (KLEIN et al., 2011). In other words, it can be understood as the ratio between the external reliability and uncertainty. In a geodetic network, we expect BNRs similar for all observations, and thus we may consider the homogeneous network.

Within this context, the aim of this study was to observe the influence of baselines length higher than the limit of $20 \mathrm{~km}$, the geodetic network design and the number of control stations used, as local geodetic networks implemented for the purpose of georeferencing. Also demonstrate the importance of using specific tests in the evaluation of the solution of the ambiguities and quality adjustment.

\section{MATERIAL AND METHODS}

In the establishment of the geodetic networks for the implementation of basic support, called STZ, five control stations of SGB (SAT93901, SAT91613, SAT93509, SAT91531 and SAT93667) were used. The SAT93901 and SAT91613 stations are located at the FCAV/UNESP-Câmpus, located in Jaboticabal - state of São Paulo (SP), Brazil; the SAT93509 station, in Ribeirão PretoSP; the SAT91531 station in Guatapará-SP; and SAT93667 station in Guariba-SP. The STZ station is located in a rural area in Jaboticabal-SP.

To field observations, the GPS L1 receiver, brand Trimble, 4600LS model was used, with horizontal accuracy of $\pm\left(5 \mathrm{~mm}+1 \mathrm{~mm} \mathrm{~km}^{-1}\right)$ and vertical accuracy $\pm\left(10 \mathrm{~mm}+2 \mathrm{~mm} \mathrm{~km}^{-1}\right)$, both to 
baseline $\leq 10 \mathrm{~km}$ (TRIMBLE NAVIGATIONLIMITED, 1997). The positioning method used was the relative static with time screening for two to four hours.

To test the influence of the baseline length, geometry and number of control stations in local geodetic network, seven networks were established (described in Table 1).

TABLE 1. Established local geodetic networks (LGN).

\begin{tabular}{|c|c|c|c|c|}
\hline $\begin{array}{l}\text { Local Geodetic } \\
\text { Network }\end{array}$ & Used Control Station Baseline & Length (km) & Geometry & Observation \\
\hline LGN1 & $\begin{array}{l}\text { SAT93509 } \\
\text { SAT91531 }\end{array}$ & $\begin{array}{l}32 \\
23\end{array}$ & $\begin{array}{l}\text { Approximately } \\
\text { uniform }\end{array}$ & $\begin{array}{l}\text { Lengths higher then the } \\
\text { standard limit }\end{array}$ \\
\hline LGN2 & $\begin{array}{l}\text { SAT91613 } \\
\text { SAT93901 }\end{array}$ & $\begin{array}{l}16 \\
15\end{array}$ & Not uniform & Irregular geometry \\
\hline LGN3 & $\begin{array}{l}\text { SAT91613 } \\
\text { SAT93667 }\end{array}$ & $\begin{array}{l}16 \\
10\end{array}$ & $\begin{array}{l}\text { Approximately } \\
\text { uniform }\end{array}$ & Standard-situation \\
\hline LGN4 & $\begin{array}{l}\text { SAT93901 } \\
\text { SAT93667 }\end{array}$ & $\begin{array}{l}15 \\
10\end{array}$ & $\begin{array}{l}\text { Approximately } \\
\text { uniform }\end{array}$ & Standard-situation \\
\hline LGN5 & $\begin{array}{l}\text { SAT93509 } \\
\text { SAT91531 } \\
\text { SAT93667 }\end{array}$ & $\begin{array}{l}32 \\
23 \\
10\end{array}$ & - & $\begin{array}{l}\text { Use of one control station } \\
\text { more than the required } \\
\text { minimum }\end{array}$ \\
\hline LGN6 & $\begin{array}{l}\text { SAT93509 } \\
\text { SAT91531 } \\
\text { SAT93667 } \\
\text { SAT93901 }\end{array}$ & $\begin{array}{l}32 \\
23 \\
10 \\
15\end{array}$ & - & $\begin{array}{l}\text { Use of two control stations } \\
\text { more than the required } \\
\text { minimum }\end{array}$ \\
\hline LGN7 & $\begin{array}{l}\text { SAT93509 } \\
\text { SAT91531 } \\
\text { SAT93667 } \\
\text { SAT93901 } \\
\text { SAT91613 }\end{array}$ & $\begin{array}{l}32 \\
23 \\
10 \\
15 \\
16\end{array}$ & - & $\begin{array}{c}\text { Use of three control stations } \\
\text { more than the required } \\
\text { minimum }\end{array}$ \\
\hline
\end{tabular}

Figure 1 shows the geographic distribution of the control stations used, the basic support STZ station and their established LGNs; stands out the LGN1 with an approximately regular geometry and the LGN2 with an irregular geometry.

The processing and the adjustment were performed in the LeicaGeo Office 4.0 (LGO) postprocessing system. The reference system used was SIRGAS2000. The transformations of geodetic curvilinear coordinates to Cartesian-plane (Universal Transverse Mercator - UTM projection system) were performed by the post-processing system of the GPS observables and we adopted the Time Zone 22 (Central Meridian $-51^{\circ}$ ). The method adopted for the adjustment of geodetic networks was the Method of Least Squares - Linear Parametric Model, as described by GHILANI \& WOLF (2006). For exchange of GPS observables, the RINEX format was used. 


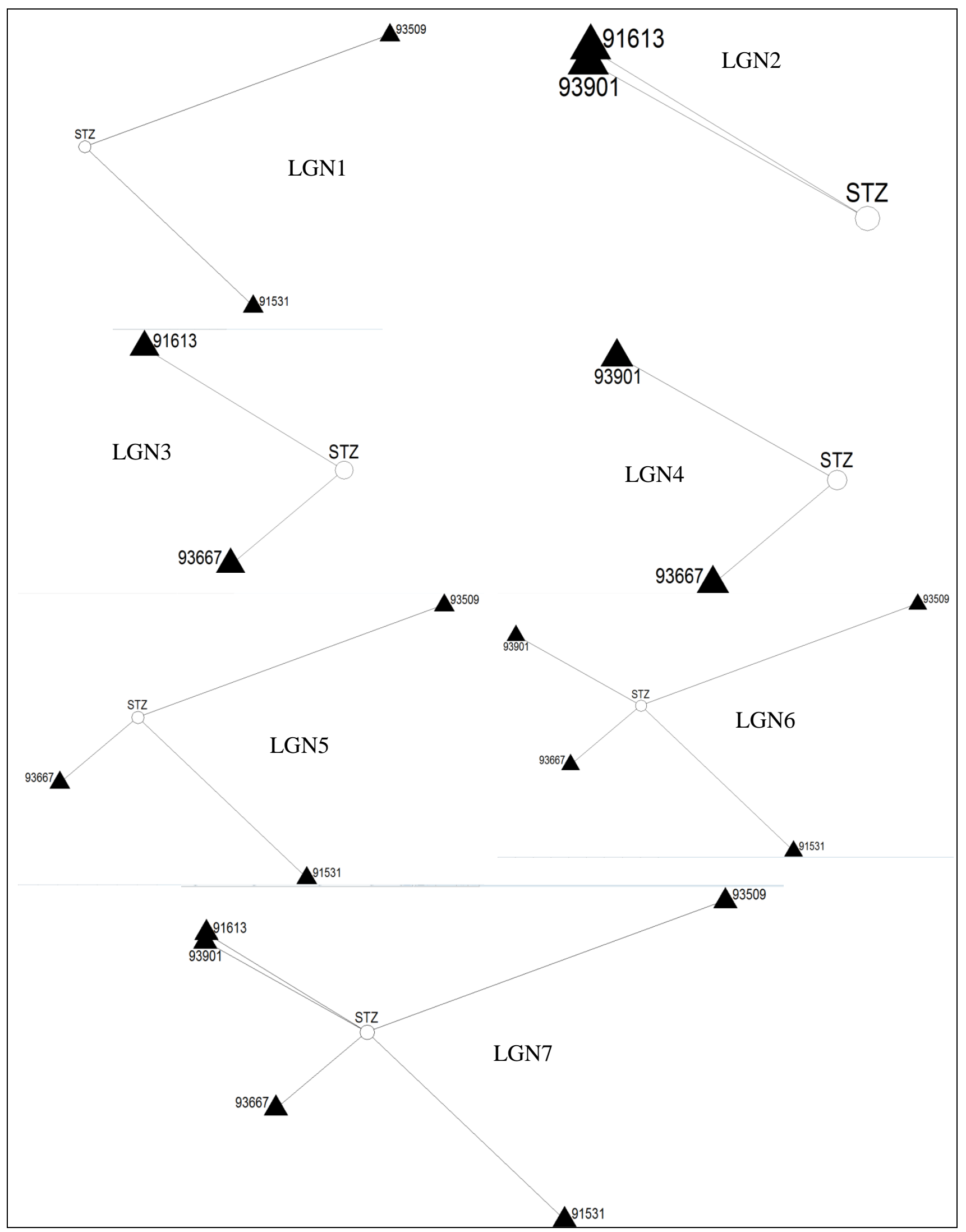

FIGURE 1. Established local geodetic networks (LGN) design.

The first analysis was performed to evaluate the fixed solution obtained in baselines of LGNs. For this evaluation, the Trimble Business Center (TBC) v. 2.5 system was used, and the measures used were the Root Mean Square (RMS), indicating in this case the solution quality based solely on 
the measurement noise of the observations of the satellite range, regardless of the geometry of these (TRIMBLE BUSINESS CENTER, 2011), and the Ratio test. As reference values for these tests, the values suggested by the TBC system were adopted. The compatibility of the Positional Precision (PP) attained for each vector (Equation 1) with the expected accuracy was also verified, and this was determined from the nominal horizontal accuracy stated by the manufacturer depending on the length of the vector.

$$
P P=\sqrt{\sigma_{E}^{2}+\sigma_{N}^{2}}
$$

where,

$P P$ - positional precision of the point;

$\sigma_{E^{-}}$standard deviation of the east coordinate of the implanted station, and

$\sigma_{N^{-}}$standard deviation of the north coordinate of the implanted station.

After the evaluation of processing of the baselines, the adjustment of the respective statistical analysis was performed. Initially, we applied the GTM (F Test) to compare the variances a priori and a posteriori. For detection of gross errors in the observations, we applied the Data Snooping Test (W Test) and the certain external (MDB) and internal (BNR) reliabilities. For the tests, we used the software LGO and adopted the values of $\alpha=5 \%$ and $1-\beta=80 \%$ (power of the test). It is noteworthy that significant values for the $\mathrm{W}$ and $\mathrm{F}$ Tests indicate failure in its tests, i.e., the $\mathrm{F}$ Test indicates a significant difference between the variances a priori and a posteriori and the $\mathrm{W}$ Test the presence of gross error in the tested observation.

Besides the detection of gross errors, we evaluated the quality of the adjustment of the geodetic network in the form of the standard deviation of the final coordinates and also of the PP (Equation 1), verifying its compatibility with the limit of $100 \mathrm{~mm}$ required by the standard georeferencing for basic support, Class C1 points (INCRA, 2010; SILVA \& MONICO, 2006; AX \& MONICO, 2004; TEIXEIRA \& FERREIRA, 2003).

As a final analysis, the differences between the position given by the STZ station obtained in different geodetic network coordinates were recorded. These differences were also compared with the limit of $100 \mathrm{~mm}$ proposed by the standard.

It is noteworthy that the PP of the flat-rectangular coordinates (UTM) of the control stations used is compatible with the established value, since it is well below the $100 \mathrm{~mm}$ required by the standard for Class C1. A fundamental fact, because the final error of the coordinates of the basic support is the result of the errors of the departure station (control station) and the vectors generated in the survey.

\section{RESULTS AND DISCUSSION}

Table 2 shows the results of processing of baselines and their evaluation. In this, there is the length of the vectors (flat distance), the occupation time, PDOPs, the solution reached, the validation parameters of the solution (RMS and Ratio test), the observed positional and nominal accuracy (confidence level of 63.21\%).

As shown in Table 2, all baselines reached the fixed solution in determining the integer ambiguities. The values found for RMS were satisfactory, because were lower than $0.03 \mathrm{~m}$, reference suggested by the TBC system. However, the Ratio test presented regular values (1.5 to 3.0), and only the 93901-STZ baseline presented a more suitable value (higher than 3.0), limit values also suggested by the TBC system and MONICO (2008). It is noteworthy that the baselines with theoretically worst solution (lower Ratio test) were those which had, during the time of screening, the highest value of PDOP (91613-STZ and 91531-STZ baselines) and not the highest length (93509-STZ baseline). Regarding to the PPs found for the baselines (observed values), we 
noted that it presented values lower than or equal to $1 \mathrm{~mm}$; values below the expected (nominal values). These values, extremely low for the baselines PP, were expected because, in general, the results of the post-processing of GPS observables are always optimistic (ISHIKAWA \& BARROS, 2010). From this fact, we can infer that assess the quality of the solution of a baseline only by the uncertain final, without considering some sort of validation of the test solution, can lead to overestimate the quality of the survey.

TABLE 2. Results from the processing of baselines and their evaluation.

\begin{tabular}{|c|c|c|c|c|c|c|c|c|c|}
\hline \multirow[t]{2}{*}{ Baseline } & \multirow{2}{*}{$\begin{array}{c}\text { Flat } \\
\text { Distance (m) }\end{array}$} & \multirow{2}{*}{$\begin{array}{c}\text { Occupation } \\
\text { time }\end{array}$} & \multicolumn{2}{|c|}{ PDOP } & \multirow[t]{2}{*}{ Solution } & \multirow{2}{*}{$\begin{array}{c}\mathrm{RMS}^{1} \\
(\mathrm{~m})\end{array}$} & \multirow{2}{*}{$\begin{array}{c}\text { Ratio }^{1} \\
\text { Test }\end{array}$} & \multicolumn{2}{|c|}{$\begin{array}{c}\text { Positional } \\
\text { Precision (m) }\end{array}$} \\
\hline & & & Min. & Max. & & & & Observed & Nominal \\
\hline 91613-STZ & $15,754.394$ & 2h4min & 2.4 & 12.1 & Fixed & 0.029 & 1.7 & 0.001 & 0.021 \\
\hline 93901-STZ & $15,457.758$ & $2 \mathrm{~h} 6 \mathrm{~min}$ & 2.3 & 3.9 & Fixed & 0.015 & 3.1 & 0.001 & 0.020 \\
\hline 93667-STZ & $9,982.915$ & $2 \mathrm{~h} 0 \mathrm{~min}$ & 2.4 & 4.4 & Fixed & - & - & 0.001 & 0.015 \\
\hline 93509-STZ & $32,063.907$ & 4h1min & 2.2 & 4.2 & Fixed & 0.018 & 2.1 & 0.000 & 0.037 \\
\hline 91531-STZ & 22,897.994 & 4h5min & 2.1 & 11.4 & Fixed & 0.026 & 1.7 & 0.001 & 0.028 \\
\hline
\end{tabular}

Table 3 displays the adjusted coordinates (curvilinear and flat-rectangular geodetic, UTM System), uncertainties (standard deviations) and PP obtained in different LGNs.

TABLE 3. Curvilinear and flat-rectangular coordinates (UTM Projection System), standard deviations and positional precision of the station STZ obtained in different LGNs. SIRGAS2000 Reference System, Zone 22.

\begin{tabular}{|c|c|c|c|c|c|}
\hline \multirow{2}{*}{ Local Geodetic Network } & \multicolumn{2}{|c|}{ Coordinates } & \multirow{2}{*}{$\begin{array}{c}\text { Standard } \\
\text { Deviation }(\mathrm{m})\end{array}$} & \multicolumn{2}{|c|}{ Positional Precision (m) } \\
\hline & Curvilinear & Flat-rectangular (m) & & Observed & Normalized \\
\hline \multirow[t]{2}{*}{ LGN1 } & 21ํ18'26.1851"S & N 7,641,181.831 & 0.019 & \multirow{2}{*}{0.025} & \multirow{2}{*}{0.100} \\
\hline & $48^{\circ} 09^{\prime 20.2676 " W}$ & E 795,092.586 & 0.017 & & \\
\hline \multirow{2}{*}{ LGN2 } & $21^{\circ} 18 ' 26.1841^{\prime S}$ & N 7,641,181.860 & 0.004 & \multirow{2}{*}{0.006} & \multirow{2}{*}{0.100} \\
\hline & $48^{\circ} 09^{\prime} 20.2644^{\prime \prime W}$ & E $795,092.680$ & 0.004 & & \\
\hline \multirow[t]{2}{*}{ LGN3 } & $21^{\circ} 18 ' 26.1847 " \mathrm{~S}$ & N 7,641,181.842 & 0.012 & \multirow{2}{*}{0.017} & \multirow{2}{*}{0.100} \\
\hline & $48^{\circ} 09^{\prime} 20.2641^{\prime \prime W}$ & E $795,092.687$ & 0.012 & & \\
\hline \multirow{2}{*}{ LGN4 } & $21^{\circ} 18 ' 26.1846^{\prime \prime S}$ & N 7,641,181.844 & 0.013 & \multirow{2}{*}{0.018} & \multirow{2}{*}{0.100} \\
\hline & $48^{\circ} 09^{\prime} 20.2642^{\prime \prime W}$ & E 795,092.684 & 0.012 & & \\
\hline \multirow[t]{2}{*}{ LGN5 } & $21^{\circ} 18 ' 26.1844^{\prime \prime S}$ & N 7,641,181.851 & 0.007 & \multirow{2}{*}{0.009} & \multirow{2}{*}{0.100} \\
\hline & $48^{\circ} 09^{\prime} 20.2650^{\prime \prime} \mathrm{W}$ & E 795,092.661 & 0.006 & & \\
\hline \multirow{2}{*}{ LGN6 } & $21^{\circ} 18 ' 26.1843^{\prime \prime S}$ & N 7,641,181.854 & 0.006 & \multirow{2}{*}{0.008} & \multirow{2}{*}{0.100} \\
\hline & $48^{\circ} 09^{\prime} 20.2651^{\prime \prime W}$ & E 795,092.657 & 0.005 & & \\
\hline \multirow[t]{2}{*}{ LGN7 } & $21^{\circ} 18 ' 26.1843^{\prime \prime S}$ & N 7,641,181.854 & 0.005 & \multirow{2}{*}{0.007} & \multirow{2}{*}{0.100} \\
\hline & $48^{\circ} 09^{\prime 20.2651 " W}$ & E 795,092.659 & 0.005 & & \\
\hline
\end{tabular}

The results, shown in Table 3, indicate that LGN2 presented the lowest deviations, while LGN1, the higher ones. Thus, as indicated by EVEN-TZUR \& PAPO (1996) apud MARINI \& MONICO (2003), the geometry of the network does not interfere in the quality, however the distance from the baseline does. Also, as expected, a larger number of control stations provided minor deviations (LGNs5, 6 and 7) in relation to the networks that used only the minimum number of stations (LGNs1, 3 and 4). We emphasize that the deviations were decreasing as the number of stations was increasing (LGNs5, 6 and 7). The fact that the LGN2 have presented smaller deviations from LGNs5 and 6 may be explained by the latter using baseline lengths higher than those of LGN2. It is noteworthy that the PP of LGN7 was only $1 \mathrm{~mm}$ above the LGN1, so even using two baselines above the limit of $20 \mathrm{~km}$, the use of a larger number of control stations yielded almost similar results of LGN2 ones. 
For purposes of evaluation of the adjustment made, we applied the GTM in the form of F Test, and the results obtained are shown in Table 4. In this, we note that only the LGN2 was approved in GTM (F Test), with 5\% level of significance. This fact may be explained by the low values of deviations (the lowest of all LGNs) achieved this LGN (Table 3).

The acceptance failure of GTM indicates that the variances a priori and a posteriori differ statistically. This failure may indicate the occurrence of gross errors, but we recommend the application of specific statistical tests for this purpose, because an erroneous attribution of weights can also lead to the occurrence of high waste and hence a failure in GTM (GONÇALVES et al., 2007).

For the detection of gross errors, we applied the DataSnoopy Test (W Test) for the observations. We also determined external (MDB) and internal (BNR) reliabilities. The results are shown in Table 4, with only the higher and lower values of MDB and BNR achieved for each LGN with their results of $\mathrm{W}$ Test, as well as the observations that have not been approved by the W Test.

TABLE 4. Results from the TGM (F Test), from DataSnoopy Test (W Test) and the highest and lowest values of the internal (MDB) and external (BNR) reliabilities, obtained for the observations. Critical value of $\mathrm{F}$ equal to 1.89 and $\mathrm{W}$ equal to 1.96 (significance level of $5 \%)$.

\begin{tabular}{|c|c|c|c|c|c|}
\hline Local Geodetic Network & $\mathrm{F}^{\text {Test }^{1}}$ & Observation $^{2}$ & MDB (m) & BNR & W Test $^{1}$ \\
\hline \multirow{3}{*}{ LGN1 } & \multirow{3}{*}{$60.87^{*}$} & $\mathrm{DX}_{91531-\mathrm{STZ}}$ & 0.388 & 8.0 & -1.71 \\
\hline & & $\mathrm{DX}_{93509-\mathrm{STZ}}$ & 0.388 & 14.7 & 1.71 \\
\hline & & $\mathrm{DZ}_{91531-\mathrm{STZ}}$ & 0.164 & 3.2 & -0.79 \\
\hline \multirow{2}{*}{ LGN2 } & \multirow{2}{*}{1.31} & DX $_{93901-S T Z}$ & 0.038 & 6.5 & 1.45 \\
\hline & & $\mathrm{DZ}_{91613-\mathrm{STZ}}$ & 0.031 & 2.0 & -0.52 \\
\hline \multirow{3}{*}{ LGN3 } & \multirow{3}{*}{$25.07^{*}$} & $\mathrm{DX}_{93667-\mathrm{STZ}}$ & 0.162 & 1.2 & 1.95 \\
\hline & & $\mathrm{DY}_{91613-\mathrm{STZ}}$ & 0.153 & 2.5 & -0.25 \\
\hline & & $\mathrm{DZ}_{93667-\mathrm{STZ}}$ & 0.071 & 2.3 & $-2.12^{*}$ \\
\hline \multirow{3}{*}{ LGN4 } & \multirow{3}{*}{$34.00^{*}$} & $\mathrm{DX}_{93901-\mathrm{STZ}}$ & 0.106 & 2.6 & -0.35 \\
\hline & & $\mathrm{DX}_{93667-\mathrm{STZ}}$ & 0.186 & 1.1 & 1.51 \\
\hline & & $\mathrm{DZ}_{93667-\mathrm{STZ}}$ & 0.079 & 2.1 & $-2.21^{*}$ \\
\hline \multirow{4}{*}{ LGN5 } & \multirow{4}{*}{$41.18^{*}$} & $\mathrm{DX}_{91531-\mathrm{STZ}}$ & 0.290 & 7.2 & $-2.94^{*}$ \\
\hline & & $\mathrm{DX}_{93667-\mathrm{STZ}}$ & 0.278 & 0.2 & $5.21^{*}$ \\
\hline & & $\mathrm{DY}_{93667-\mathrm{STZ}}$ & 0.328 & 0.2 & $3.57^{*}$ \\
\hline & & $\mathrm{DZ}_{93667-\mathrm{STZ}}$ & 0.073 & 0.9 & $-2.41^{*}$ \\
\hline \multirow{5}{*}{ LGN6 } & \multirow{5}{*}{$32.02^{*}$} & DX $_{91531-S T Z}$ & 0.255 & 7.2 & $-3.26^{*}$ \\
\hline & & $\mathrm{DZ}_{93509-\mathrm{STZ}}$ & 0.062 & 2.8 & -0.04 \\
\hline & & $\mathrm{DX}_{93667-\mathrm{STZ}}$ & 0.245 & 0.2 & $5.94^{*}$ \\
\hline & & $\mathrm{DY}_{93667-\mathrm{STZ}}$ & 0.290 & 0.2 & $4.03^{*}$ \\
\hline & & $\mathrm{DZ}_{93667-\mathrm{STZ}}$ & 0.329 & 0.2 & $2.18^{*}$ \\
\hline \multirow{5}{*}{ LGN7 } & \multirow{5}{*}{$31.15^{*}$} & $\mathrm{DX}_{91531-\mathrm{STZ}}$ & 0.251 & 7.2 & $-3.29^{*}$ \\
\hline & & $\mathrm{DZ}_{93509-\mathrm{STZ}}$ & 0.061 & 2.8 & -0.09 \\
\hline & & $\mathrm{DX}_{93667-\mathrm{STZ}}$ & 0.242 & 0.2 & $6.01^{*}$ \\
\hline & & $\mathrm{DY}_{93667-\mathrm{STZ}}$ & 0.286 & 0.2 & $4.07^{*}$ \\
\hline & & $\mathrm{DZ}_{93667-\mathrm{STZ}}$ & 0.324 & 0.2 & $2.21^{*}$ \\
\hline
\end{tabular}

${ }^{1}$ Numbers marked with * indicates significant values at 5\% level.

${ }^{2} \mathrm{DX}$, DY and DZ indicates the observed vector components.

As shown in Table 4, we do not detected any gross errors in the LGN2 (W Test not significant), an expected fact, because LGN2 had already been previously approved in GTM (Table 4). The LGN1, despite being reproved in GTM, also showed no gross errors, indicating that even when an adjustment is reproved in GTM it does not necessarily contain gross errors, as stated by GONÇALVES et al. (2007). 
In LGNs3, 4, 5, 6 and 7, we detected gross error to the DZ93667-STz observation. In LGNs5, 6 and 7, gross errors were detected for the DX and DY components of the 93667-STZ vector. The fact that errors have been identified in other components of the vector 93667-STZ in addition to the DZ component, in these geodetic networks, may be explained by the use of a larger number of observations in relation to LGN3 and 4. In LGNs5, 6 and 7 a gross error was detected in DX D1531-STZ observation. The LGN1 also made use of the $\mathrm{DX}_{91531-\mathrm{sTz}}$ observation, however the gross error was not detected, which may be explained by the same argument above (larger number of observations in LGNs5, 6 and 7). However, even if no gross error has been detected, this observation, along with the $\mathrm{DX}_{93509-\mathrm{STZ}}$ in LGN1, presented the worst internal reliability (MDB).

The results of the detection of gross errors indicated that the 93667-STZ vector and the DX component of the 91531-STZ vector showed gross errors and that these could be eliminated in the adjustment. But this procedure is only possible when it has, in the adjustment, enough degrees of freedom to perform the adjustment (TEIXEIRA \& FERREIRA, 2003). Also, as cited by GONÇALVEZ et al. (2007), the possibility of undetected gross errors increases with the increase in the number of observations, as demonstrated in LGNs5, 6 and 7. It is noteworthy that the 91531STZ baseline was one of the baselines which showed less satisfactory results in the evaluation of the solution of the ambiguity.

The internal reliability (MDB) indicates the sensitivity of the detection of gross errors, and the higher the value, the lower the sensitivity. Thus, Table 4 shows that LGN2 showed the best results, because the values of MDB indicated the possibility of identifying gross errors on order of centimeters; it also showed the smallest difference between the highest and lowest value for the internal reliability. LGN1 presented the worst internal reliability, indicating the possibility of identifying gross errors from approximately four decimeters and also presented one of the greatest disparities between the highest and lowest value for the MDB. It is noteworthy that the best result presented by LGN2 was already signaled in its adoption by GTM and W Test, which indicated the absence of detectable gross errors. Regarding the LGN1, the result of its internal reliability may explain the fact of its rejection in GTM and approval in W Test. The W Test identified no gross error due to its low internal reliability, i.e., the error should have a magnitude higher than $39 \mathrm{~cm}$. It is noteworthy also that the network used the observations relative to 91531-STZ vector, which when used in conjunction with other observations, such as the LGNs3, 4 and 5, presented detectable gross error by the $\mathrm{W}$ Test.

The LGNs3 and 4 that represented standard situations, i.e., relatively uniform geometry and length of baseline within the limit of $20 \mathrm{~km}$, showed similar internal reliability, a fact expected because of the similarity of conditions in the establishment of these networks. On the other hand, LGNs3, 4 and 5 showed reliability slightly lower than the internal LGNs3 and 4 . This fact may be explained by the use of a larger number of observations with probable gross errors.

The external reliability (BNR) indicates the influence of gross error in the adjusted value, and the higher the value, the greater the influence. Also, it is expected that the BNR has similar order of magnitude in the observations that compose a geodetic network, indicating a homogeneous network. Thus, Table 4 shows that LGNs3 and 4 showed the best values for the BNR, followed by LGN1. The LGNs5, 6 and 7 presented BNR with similar values and LGN1 the worst value for external reliability, indicating that in this network a possible gross error would have greater influence on the adjusted values .

Regarding the homogeneity of geodetic networks, the values in Table 4 show that LGNs3 and 4 showed less variation between the highest and lowest value of BNR; thus, these networks have a more homogeneous character in relation to others. LGN2 showed less variation and the LGNs5, 6 and 7 showed similar variations. Finally, LGN1 showed the greatest variation of external reliability, having the lowest homogeneity in relation to other networks.

The last analysis was to assess the differences between the positions determined by the STZ station coordinates, obtained in LGNs. All differences, approximately, are smaller or equal to the 
limit of 100mm for PP required by the georeferencing standard for basic points of support. Thus, despite the different positioning qualities found in LGNs, these did not interfere to generate differences between the positions obtained for the STZ station, above the quality limit.

\section{CONCLUSIONS}

Increasing the number of control stations improved the network quality, and could even be an alternative to when it is not possible to strictly respect the limit of $20 \mathrm{~km}$. The irregular geometry did not influence the quality of the results, however the length of baseline did, worsening the accuracy of the adjusted network coordinates; nevertheless, even for baselines longer than $20 \mathrm{~km}$ it was possible to obtain the positional precision required by the standard georeferencing of rural properties. It is very important to perform validation of the ambiguities, because the fixed solution may not guarantee the quality of work. The use of different statistical tests both for the evaluation of the solution ambiguities and to the evaluation of the adjustment allows greater clarity in the evaluation of the results, enabling inadequate observations to be eliminated.

\section{REFERENCES}

ARANA, J.M.; ISHIKAWA, M.I.; MONICO, J.F.G. Influência do tempo de rastreio e PDOP na coleta de dados GPS. In: SEMINÁRIO DE IMPACTO DAS NOVAS TECNOLOGIAS NA ENGENHARIA CARTOGRÁFICA / ENGENHARIA CARTOGRÁFICA, 20., FCT/UNESP, 1997, Presidente Prudente. Anais...PresidentePrudente: UNESP, 1997. v.1. p.109-114.

BAARDA, W. A Testing procedure for use in geodetic networks. $5^{\text {th }}$ ed. Delft: Netherlands Geodetic Comission, 1968. v.2.

ISHIKAWA, M.I.; BARROS, Z.X. Determinação das coordenadas dos vértices limítrofes de imóveis rurais utilizando-se do posicionamento GPS. Energia na Agricultura, Botucatu, v.25, p.103-120, 2010.

CATEN, A.T.; ROBAIANA, A.D. Planejamento de missão e tempo de rastreio em levantamentos geodésicos.In: CONGRESSO BRASILEIRO DE ENGENHARIA AGRICOLA, 34., 2005, Canoas. Anais... Canoas: SBEA, 2005. 1 CD-ROM.

COSTA NETO, P.L.O. Estatítica. 2.ed. São Paulo: Edgar Blucher, 2002. 280 p.

FREITAS, S.R.C. Estabelecimento de uma base de alta precisão para levantamentos geodésicos em

Santa Catarina. In: CONGRESSO BRASILEIRO DE CADASTRO TÉCNICO MULTIFINALITÁRIO, 1998, Florianópolis. Anais... Florianópolis: Universidade Federal de Santa Catarina, 1998.

GRANEMANN, D.C.; FAGION, P.L.; NADAL，C.A.; VEIGA, L.A.K.; FREITAS, S.R.C. Estabelecimento de uma rede geodésica para o monitoramento de estruturas: estudo de caso na usina hidrelétrica Salto Caxias. Boletim de CiênciasGeodésicas, Curitiba, v. 14, n. 2, p.200-220, 2008.

GÖKALP, E.; GÜNGÖR, O.; BOZ, Y. Evaluation of different outlier detection methods for GPS networks. Sensors, Basel, v.8, p. 7.344-7.358, 2008.

GONÇALVES, R.P.; SILVA, A.S.; MAROTTA, G.S.; ANDRADE, R.J.O.; ASSIS, L.C. Identificação de erros grosseiros utilizando Teste Qui-Quadrado e Teste Tau. In: SIMPÓSIO BRASILEIRO DE GEOMÁTICA, 2., 2007, Presidente Prudente. Anais...Presidente Prudente: UNESP/FCT, 2007.

GHILANI, C. D.; WOLF, P. R. Adjustment computations:Spatial data analysis. 4.ed. New Jersey: John Wiley \& Sons, 2006. 611 p.

GULLU, M.; YILMAZ, I. Outlier detection for geodetic nets using ADALINE learning algorithm.Scientific Researchand Essays, Nairobi, v.5, n.5, p. 440-447, 2010. 
HOLZSCHUH, M. L.; SAPUCCI, L. F.; MONICO, J. F. G. Avaliação de perfis atmosféricos de rádio ocultação GPS do satélite CHAMP sobre a América do Sul. Revista Brasileira de Meteorologia, São José dos Campos, v. 25, p. 147-155, 2010. Disponível em: $<$ http://www.scielo.br/scielo.php?script=sci_arttext\&pid=S0102-77862010000200001\&nrm=iso >

INCRA - Instituto Nacional de Colonização e Reforma Agrária. Norma técnica para georreferenciamento de imóveis rurais:aplicada à Lei 10.267. 2.ed. Brasília: 2010. 86 p.

KLEIN, I.; MATSUOKA, M.T.; SOUZA, S.F. Teoria de confiabilidade generalizada para múltiplos outliers: apresentação, discussão e comparação com a teoria convencional. Boletim de Ciências Geodésicas, Curitiba, v. 17, n.4, p.519-548, 2011.

MACHADO, W.C.; MONICO, J.F.G. Controle de qualidade do ajustamento recursivo de observações GPS em linhas de base curtas. Boletim de Ciências Geodésicas, Curitiba, v. 10, n.2, p.123-140, 2004.

MARINI, M.C.; MONICO, J.G. Aspectos da otimização e processamento de redes GPS. Pesquisas em Geociências. Porto Alegre, v. 30, n.2, p.51-60, 2003.

MONICO, J.F.G. Posicionamento pelo NAVSTAR - GPS. Descrição, fundamentos e aplicações. Presidente Prudente: UNESP, 2.ed., 2008. 480 p.

MONICO, J.F.G.; THOMAZ, H.R.; SILVA, F.G.; MALDONATO, V.C. Rede Geodésica do Município de Paulínia: Integração com a rede GPS do Estado de São Paulo e RBMC. In: CONGRESSO BRASILEIRO DE CADASTRO TÉCNICO MULTIFINALITÁRIO, 1998, Anais... Florianópolis: Universidade Federal de Santa Catarina, 1998.

OLIVEIRA, R.; DALMOLIN, Q. A Influência da redundância da observação sobre a precisão dos parâmetros. Boletim de CiênciasGeodésicas.Curitiba, 2008, v.14, n.3, p.295-315.

POPE, A.J. The statistics of residuals and outlier detection of outliers. Rockville: NOAA, 1976, p.254. (TechnicalReports NOS 65, NGS1).

RODRIGUES, D.D. Redes geodésicas de precisão no Estado de Minas Gerais: avaliação de diferentes estratégias de processamento e ajustamento. 2002. 222 f. Tese (Doutorado em Engenharia) - Escola Politécnica, Universidade de São Paulo, 2002.

ROSALEN, D.L. O novo paradigma no ordenamento do território rural brasileiro mediante a Lei 10.267. In: CONGRESSO IBÉRICO DE AGRO-ENGENHARIA, 6., 2011, Évora. Anais... Évora: Universidade de Évora, 2011a.

ROSALEN, D.L.; RODRIGUES, M.S.; CHIODEROLI, C.A.; BRANDÃO, F.J.; SIQUEIRA, D.S. GPS receivers for georeferencing of spatial variability of soil attributes. Engenharia Agrícola, Jaboticabal, v.31, n.6, p.1162-1169, nov.dez.2011b.

SILVA, H.A.; MONICO, J.F.G. Analise das precisões das coordenadas no ajustamento de redes GPS. In: CONGRESSO BRASILEIRO DE CADASTRO TÉCNICO MULTIFINALITÁRIO, 2006, Florianópolis. Anais... Florianópolis: Universidade Federal de Santa Catarina, 2006.

TEIXEIRA, N.N.; FERREIRA, L.D.D. Análise da confiabilidade de redes geodésicas. Boletim Ciências Geodésica, Curitiba, v.9, n.2, p. 199-216, 2003.

TRIMBLE NAVIGATION LIMITED. 4600LS Surveyor operation manual. Sunnyvale, 1997.145 p. (Manual Técnico).

TRIMBLE BUSINESS CENTER.Versão2.50.TBCHelp.Dayton: Trimble Navigation Limited, 2011.

VASCONCELLOS, J.C.P.V.; BLITZKOW, D. Ajustamento de redes geodésicas GPS de densificação e extensão. In: CONGRESSO BRASILEIRO DE CARTOGRAFIA, 21., 2003, Belo Horizonte. Anais... Belo Horizonte: Sociedade Brasileira de Cartografia, 2003. 